\title{
The Impact of Supply Chain Dynamic to Competitiveness and Business Efficiency in Vietnamese Enterprises
}

\author{
Dang Quy Duong ${ }^{1} \&$ Le Trung Thanh ${ }^{1}$ \\ ${ }^{1}$ University of Economics and Business, Vietnam National University, Hanoi, Vietnam \\ Correspondence: Dang Quy Duong, University of Economics and Business, Vietnam National University, Hanoi, \\ Vietnam. Tel: 84-983-367-275. E-mail: dangquyduongts@gmail.com
}

Received: September 18, 2018

Accepted: October 17, $2018 \quad$ Online Published: October 28, 2018

doi:10.5539/ijef.v10n11p103

URL: https://doi.org/10.5539/ijef.v10n11p103

\begin{abstract}
This research aims to assess the impact of supply chain capacity as well as supply chain capacity dynamics on competitiveness and business efficiency of manufactory enterprises in Vietnam. The Research has used multivariate analysis techniques (descriptive statistics, reliability test, factor analysis, regression analysis). Research results from 205 firms have indicated that supply chain capacity does not affect the competitive advantage of enterprises but positively affects business efficiency. Meanwhile, supply chain dynamic has a positive impact on competitive advantage and performance. From this study, the author also made some suggestions to improve the competitiveness and business efficiency.
\end{abstract}

Keywords: supply chain capacity, supply chain dynamic capacity, competitiveness, enterprise's performance

\section{Introduction}

Vietnam joined the WTO and prior to joining the CPTPP and AEC are not only opportunities but also great challenges for enterprises. The issue is not only the competition among domestic enterprises but also the competitive pressure on foreign firms joining the economy. Vietnam is the place to produce some high-value industrial products such as garment, mobile phones, industrial steel, tea, and coffee. However, Vietnamese enterprises still face many difficulties in developing and managing supply chains. Supply chain management has become one of the main means for businesses to control costs and improve economic efficiency in the face of increasingly competitive markets (Hong et al., 2015).

Based on research into the enterprises, Hanifan \& Associates found that by setting the enterprise supply chain not only cutting costs and improving risk management but also generating new revenue streams and increase brand value (Hanifan et al., 2012). In order to effectively implement the supply chain, supply chain capacity and supply chain dynamics play an important role in increasing competitiveness and business efficiency (Liao et al., 2017). With traditional supply chain capabilities, often tangible resources (technology, products) are becoming familiar to every business. Supply chain resources are easy to detect and evaluate so they are easy to catch up, leading to reduced value due to popularity and visibility.

In addition, the existence of invisible resources (knowledge, leadership arts) is difficult to detect and imitate. This is the source of the dynamic capacity of enterprises (Tho \& Trang, 2009). With the development of science and technology, products are launched with shorter product lifecycles leading to continuous product innovation. At the same time, tangible changes or supply chain capabilities are easy to copy. Therefore, the dynamic factor becomes more necessary to create a competitive advantage and bring about business efficiency (Eisenhardt \& Martin, 2000). Therefore, businesses must always strive to identify, nurture, develop and use dynamic capabilities in an effective way, adapt to the changing business environment.

There are a number of studies that assess the supply chain, the competitive advantage and the business performance of the business. In particular, Liao and Associates (2017) conducted an assessment of the impact of supply chain capacity on competitive advantage for manufacturing enterprises; Hong and Associates (2017) conducted an assessment of the impact of dynamic supply chain performance on business performance; or Zott (2003), Griffith and Associates. (2006) and Eriksson (2013) both investigate the impact of dynamic supply chain dynamics on the competitive advantage and efficiency of business operations. Although the research in the world is carried out on the above issues, in the environment of Vietnamese enterprises, according to author's 
understanding, there is no study evaluating the supply chain capacity, capacity The supply chain, competitive advantage and efficiency of the business. Therefore, the author makes an assessment of the impact of supply chain capacity, the dynamic supply chain dynamics to the competitive advantage and efficiency of the business is necessary.

\section{Literature Review, Research Method}

\subsection{Literature Review}

\subsubsection{Supply Chain}

Capacity is information-driven processes that deploy company resources to achieve goals (Amit \& Schoemaker, 1993). They are the source of the company's performance in the market. Competitive search organizations help them to achieve customer expectations and deliver financial results (Liao et al., 2017). Competence means that the business needs to be able to manage and organize its activities to maximize the potential of its resources (Barney, 1991). The development of global engineering has made the life cycle of a product shortened. Therefore, supply chain capacity becomes necessary.

Supply chain capacity is the construction of a closed loop for supply chain strategy and a source of competitive advantage for firm success (Morash, 2001). Lynch and Associates (2000) categorizes supply chain capabilities into several dimensions: supply-side processing and increased value-added. Supply-side processing uses rationalized and standardized supply chain processes to analyze, distribute widely or in-depth to provide a more efficient way to distribute products and services. The total cost of distribution. Custom value-added capabilities that meet the needs of customers for special products or custom services, designed to create incremental customer value and maximize customer satisfaction and continuous improvement.

According to Liao et al. (2017); Morash et al. (1996); Lynch et al. (2000), supply chain capabilities can be divided into five categories: supply chain processing; product/service standardization and integration; improve the quality of products and services; Maintain customer and partner relationships and the ability of customers and partners to solve the problem.

\subsubsection{Supply Chain Dynamic Capacity}

When capacity is not upgraded to match change, they will gradually become less useful to the company when the business environment changes. Such situations call for dynamic capacity. Dynamic capacity can build and reorganize organizational resources to respond to changes in the business environment (Teece et al., 1997). They not only react to market changes but also actively contribute to new resources that will be useful in the future (Eisenhart \& Martin, 2000). Capacity or resources become dynamic when resources meet four characteristics: (1) Valuable; (2) Rare; (3) Difficult to replace and (4) gas imitated. Dynamic capacity will create competitive advantages and bring about business efficiency (Barney, 1986; Eisenhardt \& Martin, 2000).

Supply chain dynamics capacity builds on dynamic capacity, which is the capacity to regulate the supply chain. It is an emerging and popular concept in recent years and its essence is very elusive (Defee \& Fugate, 2010). Beske (2012) see the supply chain is a complex system. He pioneered the application of dynamic capabilities into the supply chain and proposed the dynamic capacity of the supply chain as the desired ability of this sophisticated system to cope with environmental change as well as the interests complex system inside. Gimzauskiene et al. (2015) argue that dynamic supply chain dynamics make organizations more flexible, and therefore easily and quickly adapt to market trends and address volatility market and ultimately allow the company to achieve the sustainable competitive advantage in the industry

\subsubsection{Competitive Advantage}

Competitive advantage is the extent to which an organization can create a better position than its competitors (Porter, 1985). To maximize the competitive advantage that all members of the supply chain must continually work together to serve the end consumer (McGinnis \& Vallopra, 1999). Porter (1985) suggests that the way a company associates with other companies in its value chain can affect competitive advantage, especially when external assets are created. distinct from other value chains. Adner and Helfat (2003) suggest that strategic options for sustainability may be the decisive factor that would allow companies to create the unique competitive advantage over product images and sales., market share and new market. Reducing the product development cycle time and hence the time to introduce a new product can create a comparative advantage in terms of market share, profitability and long-term competitive advantage (Karlsson \& Ahlstrom, 1999).

Over the past decade, resource-based researchers have identified a number of dynamic capabilities that create 
value, including the ability to innovate. Innovation speed is particularly important in environments characterized by intense competition (Eisenhardt \& Martin, 2000). Lin and Partners (2006) describes a framework for competing and identifying five elements: competitive pricing, high-end pricing, quality customer value, reliable delivery, and changeability. new production.

\subsection{Research Model and Hypothesis}

The research of the selected frames is the model of the Hong et al (2017); Liao \& et al (2017) with the dynamic string dynamic performance to the business output.

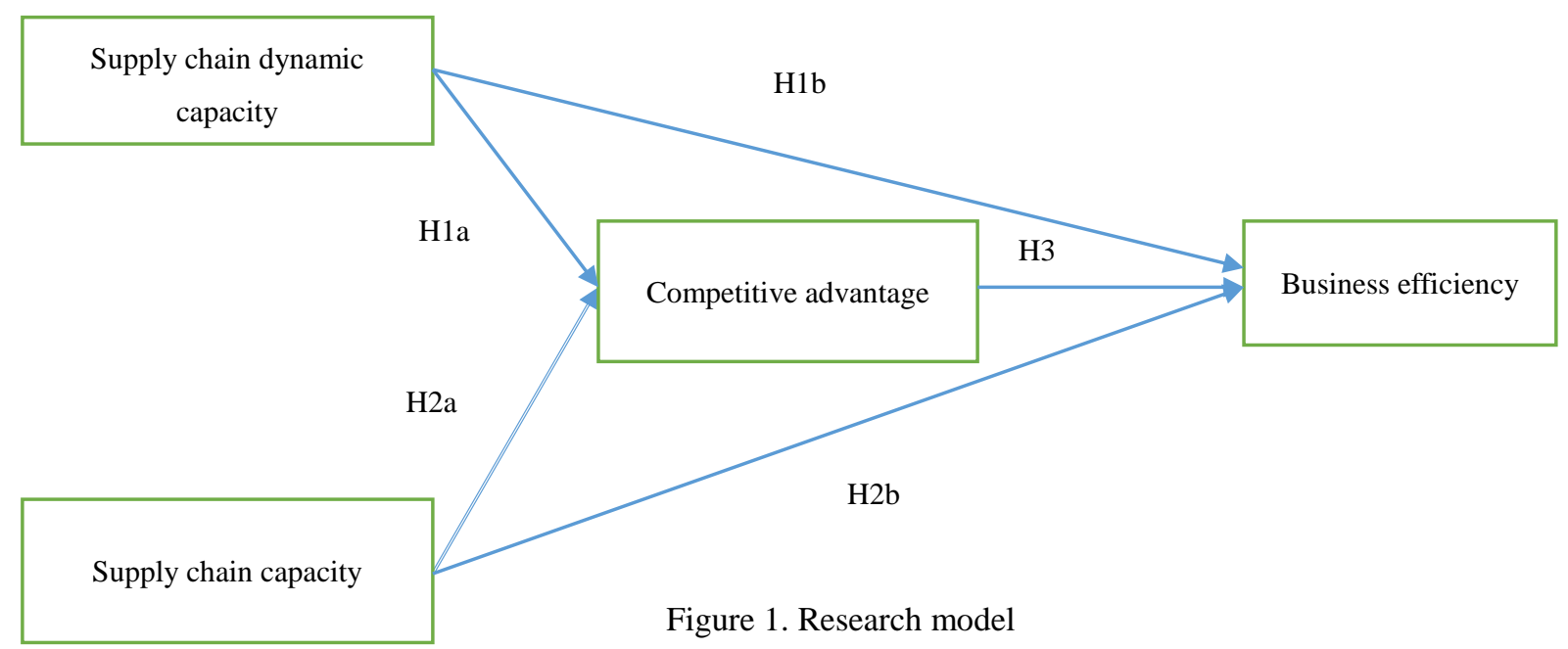

\section{Hypothesis:}

Zott (2003), Griffith et al. (2006); Eriksson (2013) confirm that dynamic capacity allows a company to gain competitive advantage and thus improve business efficiency. Menguc and Barker (2005) find similar results in terms of economic viability. Cheng et al. (2014) found that in highly competitive markets, good dynamic performance could significantly improve the company's innovative performance and new products. Therefore the hypothesis is showed as follows:

H1a: Supply chain dynamic capacity has a positive impact on competitive advantage

H1b: Supply chain dynamic capacity has a positive impact on business efficiency

Kim (2006) examined the causal linkages of competitiveness, supply chain performance, and business performance. He developed a framework for linking the strategy that integrates the company's supply chain capabilities with competitive strategies and to determine how to link those links to the company's business performance. Companies enhance the supply chain's ability to improve business performance and, ultimately, competitive advantage (Hardy et al., 2003). Thus, the author suggests the following research:

H2a: Supply chain capacity has a positive impact on competitive advantage.

H2b: Supply chain capacity has a positive impact on business efficiency.

H3: The competitive advantage has a positive effect on business efficiency.

\section{Research Method}

\subsection{Design Research}

The author uses the scale of Hong and Associates (2017) and Liao and Associates (2017 to construct the survey.) Using a 5-point Likert scale with 1 being totally disagreed and 5- Strongly agree. The survey is summarized in the following table: 
Table 1. The survey

\begin{tabular}{|c|c|c|}
\hline Code & Content & Reference \\
\hline$I$ & Supply chain capacity & \\
\hline SCC1 & The unit delivers high-quality products and fast delivery capabilities. & \multirow{5}{*}{$\begin{array}{l}\text { Hong et al. (2017); } \\
\text { Liao et al. (2017) }\end{array}$} \\
\hline $\mathrm{SCC} 2$ & $\begin{array}{l}\text { Units are ready to simplify the supply chain process and have the power to eliminate } \\
\text { unnecessary processes }\end{array}$ & \\
\hline $\mathrm{SCC} 3$ & The unit has a good relationship with customers and partners. & \\
\hline SCC4 & The unit is able to solve the problem for the customer. & \\
\hline SCC5 & Unit of ability to standardize and unify the products and services. & \\
\hline II & Supply chain dynamic capacity & \\
\hline SCDC1 & Enterprises have the ability to acquire knowledge about the supply chain & \multirow{4}{*}{ Hong et al. (2017) } \\
\hline $\mathrm{SCDC} 2$ & Enterprise-aware supply chain-oriented market & \\
\hline $\mathrm{SCDC} 3$ & Businesses have the innovation of supply chain & \\
\hline SCDC4 & Enterprise can re-establish supply chain & \\
\hline III & Competitvie advantage & \\
\hline CA1 & You have the advantage of price & \multirow{9}{*}{ Liao et al. (2017) } \\
\hline $\mathrm{CA} 2$ & Your company can provide the lowest price & \\
\hline $\mathrm{CA} 3$ & Product/service quality service to compete with competitors & \\
\hline CA4 & Your company provides reliable products and services & \\
\hline CA5 & Your company can provide timely products or services to customers. & \\
\hline CA6 & The delivery process of your product or service is quite reliable. & \\
\hline CA7 & Your company guarantees to provide market demand for your product or service & \\
\hline CA8 & Your company is usually the first to introduce new products or services to the market. & \\
\hline CA9 & Your company can quickly launch new products & \\
\hline IV & Business efficiency & \\
\hline EP1 & Business operation is always convenient & \multirow{3}{*}{$\begin{array}{l}\text { Hong et al. (2017); } \\
\text { Liao et al. (2017 }\end{array}$} \\
\hline EP2 & The market for big business & \\
\hline EP3 & Business is financially efficient & \\
\hline
\end{tabular}

\subsection{Sample}

The study was conducted through a survey of business actors involved in the supply chain. Time to conduct the survey in 7/2018. The method of collecting data online was used by the author in the study. Online survey passes via email. The sample collected was 205 valid votes. With a score of 205 , the study was found to be consistent with the sample size of Tabachnick and Fidell (2007) with a sample size of $50+8 * p=90$ (with $p=5$ Independent variables)

\subsection{Data Analysis Method}

The study sample $(\mathrm{n}=205)$ will be included in the reliability analysis through the Cronbach Alpha coefficient, crossover coefficient greater than 0.6 (Hair et al., 2006), the total variable correlation greater than 0.3 (Nunally \& Burstein, 1994); Analysis of the KMO coefficient is greater than 0.5, Bartlett's test has p-value <0.05, and the explanatory variance is greater than 50\% (Hair et al., 2006).

With factors from factor analysis, the author uses regression to find the factors that have a real impact on competitive advantage and business efficiency. The p-value of the independent variable less than 0.05 is considered to have an effect on the dependent variable.

\section{Results}

\subsection{Result of Reliability Test}

The result of the scale analysis showed that all factors were positive with Cronbach Alpha coefficients greater than 0.6 and the correlation coefficient was greater than 0.3. Once the factors have reached the confidence scale, the author conducts factor analysis. The results of the factorial analysis showed that the factors were unidirectional and the factor analysis was appropriate (KMO coefficients were greater than 0.5, Bartlett's test was statistically significant, variance greater than $50 \%$, factor weights are greater than 0.5 . Other observational variables converge similarly to the original theory (Table 2 ). 
Table 2. The result of reliability test

\begin{tabular}{lcccc}
\hline & Cronbach Alpha (items) & Corrected Item-Total Correlation (min) & KMO & TVE (\%) \\
\hline Supply chain capacity & $0.845(5)$ & 0.311 & 0.791 & 68.67 \\
Supply chain dynamic capacity & $0.881(4)$ & 0.631 & 0.888 & 56.73 \\
Competitive advantage & 0.863 (7) remove CA, CA6 & 0.528 & 0.643 & 65.07 \\
Business efficiency & $0.729(3)$ & 0.449 & \\
\hline
\end{tabular}

\subsection{Result of Regression}

After analyzing EFA, the authors obtained the regression analysis and obtained the following results:

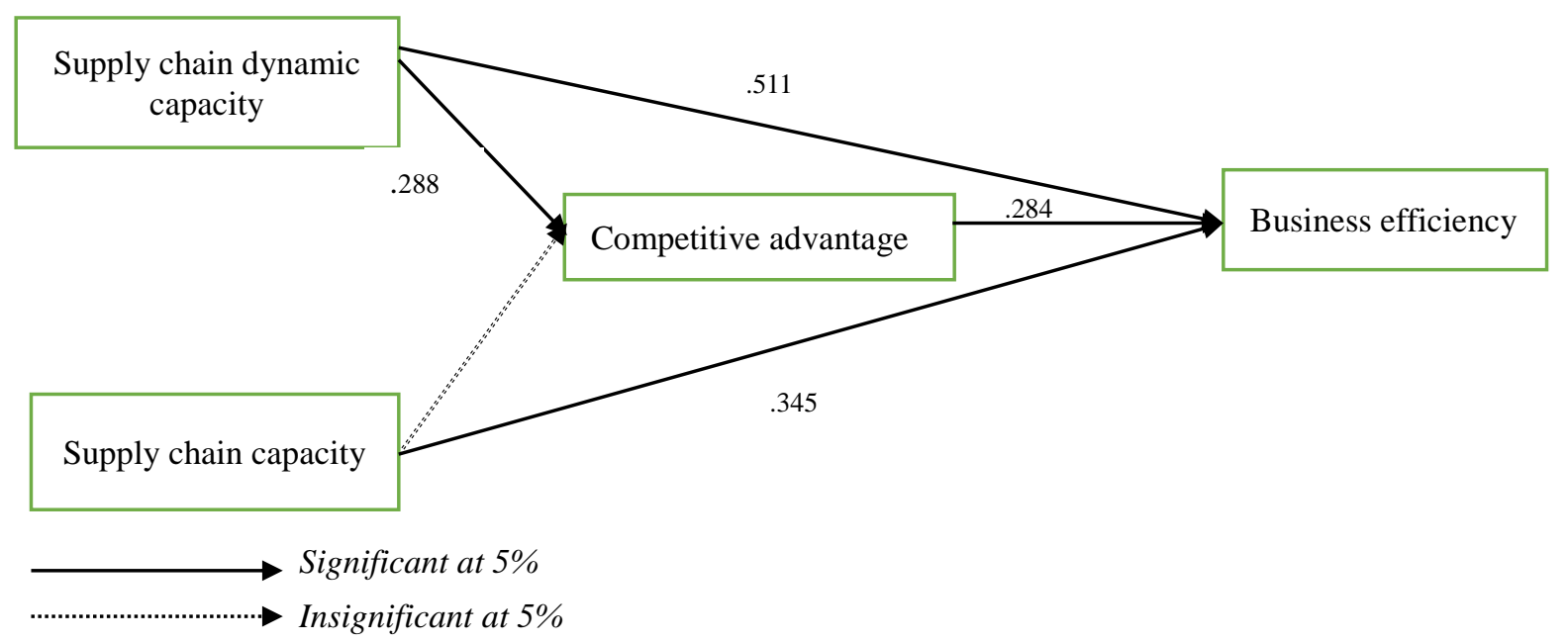

Figure 2. Result of regression

Research result shows that the supply chain dynamic capacity has a positive effect on the competitive advantage and business efficiency (p-value is less than 0.05). This indicates that H1a and H1b are accepted. The supply chain capacity factor does not affect the competitive advantage (p-value greater than 0.05) so the H2a hypothesis is rejected. At the same time, from the regression analysis, the results also show that supply chain capacity and competitive advantage have a positive impact on the business efficiency of enterprises (p-value less than 0.05). Hence $\mathrm{H} 2 \mathrm{~b}$ and $\mathrm{H} 3$ are accepted. The supply chain dynamic capacity has the strongest impact on business efficiency. The supply chain capacity factor did not affect business efficiency (p-value greater than 0.05 ). The author rejected the hypothesis $\mathrm{H} 2 \mathrm{a}$

\section{Discussion and Recomendation}

From the research results show that supply chain capacity increases the business efficiency of enterprises. It can be seen that enterprise standardization of supply chain processes and the removal of unnecessary processes will save time and costs. This results in increased business efficiency as unnecessary costs are reduced. At the same time, the good control of the quality of products makes the stable source of customers continue to be maintained in terms of quality assurance. From there, businesses can also create business efficiencies when they are able to distribute their products quickly. The results are consistent with previous researcher Kim (2006), Hardy et al. (2003). From this result, the author also made a number of briefings focused on the readiness factor to simplify the supply chain process and have the power to eliminate unnecessary processes.

However, the supply chain capacity factor does not affect the competitive advantage of the enterprises. This can indicate that even though the business is fully converged on the supply chain, this will only increase business efficiency in the short run without creating the competitive advantage for the enterprises. This threatens the business development trend of the business in the long term when there is no competitive advantage. From this, it can be seen that although tangible supply chain development strategies produce only short-term economic efficiency, in order to improve competitiveness and long-term business efficiency, enterprises need another source of interest in supply chain dynamics.

Supply chain dynamics capacity has a positive impact on the competitive advantage and business efficiency of 
enterprises. With this result, we can see that supply chain dynamics have an important role in enhancing the competitive advantage and business efficiency of enterprises. The supply chain can operate in a cyclical fashion, so continuous acquisition of knowledge of process management innovation provides product availability, processes that enhance competitive advantage and business efficiency. In addition, as firms acquire market-oriented knowledge, the supply chain of a business operates better in line with market trends. In addition to the acquisitions, innovative supply chain innovations provide breakthroughs that differentiate them from those of competitors that lead to improved competitive advantage and business efficiency. The results of the study are similar to that of Zott (2003), Griffith et al. (2006) and Eriksson (2013), Cheng et al. (2014). From this result, the author also pointed out the need to continuously invest in the development of supply chain dynamic capacity through the acquisition of new supply chain knowledge, boldly launching innovative innovations to meet market demand. school.

\section{Refferences}

Adner, R., \& Helfat, C. E. (2003). Corporate effects and dynamic managerial capabilities. Strategic Management Journal, 24(10), 1011-1025. https://doi.org/10.1002/smj.331

Amit, R., \& Schoemaker, P. J. (1993). Strategic assets and organizational rent. Strategic Management Journal, 14(1), 33-46. https://doi.org/10.1002/smj.4250140105

Barney, J. (1991). Firm resources and sustained competitive advantage. Journal of Management, 17(1), 99-120. https://doi.org/10.1177/014920639101700108

Beske, P. (2012). Dynamic capabilities and sustainable supply chain management. International Journal of $\begin{array}{lllll}\text { Physical Distribution \& } \quad \text { Logistics } & \text { Management, }\end{array}$ https://doi.org/10.1108/09600031211231344

Cheng, J. H., Chen, M. C., \& Huang, C. M. (2014). Assessing inter-organizational innovation performance through relational governance and dynamic capabilities in supply chains. Supply Chain Management, 19(2), 1-27. https://doi.org/10.1108/SCM-05-2013-0162

Defee, C. C., \& Fugate, B. S. (2010). Changing perspectives of capabilities in the dynamic supply chain era. $\begin{array}{llll}\text { International Journal of Logistics } & \text { Management, 21(2), }\end{array}$ https://doi.org/10.1108/09574091011071915

Eisenhardt, K., \& Martin, J. (2000). Dynamic capabilities: What are they? Strategic Management Journal, 21(6), 1105-21. https://doi.org/10.1002/1097-0266(200010/11)21:10/11<1105::AID-SMJ133>3.0.CO;2-E

Eriksson, T. (2013). Processes, antecedents and outcomes of dynamic capabilities. Scandinavian Journal of Management, 30(1), 65-82. https://doi.org/10.1016/j.scaman.2013.05.001

Gimzauskiene, E., Duoba, K., Pavie, X., Pinnington, A., Vilkas, M., \& Masteika, I. et al. (2015). Dynamic capabilities in supply chain management. Procedia-Social and Behavioral Sciences, 213, 830-835. https://doi.org/10.1016/j.sbspro.2015.11.485

Griffith, D. A., Noble, S. M., \& Chen, Q. (2006). The performance implications of entrepreneurial proclivity: A dynamic capabilties approach. Journal of Retailing, 82(1), 51-62. https://doi.org/10.1016/j.jretai.2005.11.007

Hair Jr, J. F., Black, W. C., Babin, B. J., Anderson, R. E., \& Tatham, R. L. (2006). Data Analysis Multivariate.

Hanifan, G. L., Sharma, A. E., \& Mehta, P. (2012). Why a sustainable supply chain is good business. Outlook, 3, $1-7$.

Hardy, C., Phillips, N., \& Lawrence, T. B. (2003). Resources, knowledge and influence: The organizational effects of inter-organizational collaboration. Journal of Management Studies, 40(2), 321-47. https://doi.org/10.1111/1467-6486.00342

Hong, Y. C., \& Moreira, M. A. (2014). Management systems and good practices related to the sustainable supply chain management. Journal of Management \& Sustainability, 4(2).

Karlsson, C., \& Ahlstrom, P. (1999). Technological level and product development cycle time. Journal of Product Innovation Management, 16(3), 352-62. https://doi.org/10.1016/S0737-6782(98)00066-6

Kim, S. W. (2009). An investigation on the direct and indirect effect of supply chain integration on firm performance. International Journal of Production Economics, 119(3), 328-346. https://doi.org/10.1016/j.ijpe.2009.03.007 
Liao, S. H., Hu, D. C., \& Ding, L. W. (2017). Assessing the influence of supply chain collaboration value innovation, supply chain capability and competitive advantage in Taiwan's networking communication industry. International Journal of Production Economics, 191, 143-153. https://doi.org/10.1016/j.jpe.2017.06.001

Lin, C., Chow, W. S., Madu, C. N., Kuei, C. H., \& Yu, P. P. (2004). A structural equation model of supply chain quality management and organizational performance. International Journal of Production Economics, 96(3), 355-365. https://doi.org/10.1016/j.ijpe.2004.05.009

Lynch, K., \& Ozment, A. (2000). The Effects of Logistics Capabilities and Strategy On Firm Performance. Journal of Business Logistics, 21(2), 47-50.

McGinnis, M. A., \& Vallopra, R. M. (1999). Purchasing and supplier involvement in process improvement: A source of competitive advantage. Journal of Supply Chain Management, 35(4), 42-50. https://doi.org/10.1111/j.1745-493X.1999.tb00243.x

Menguc, B., \& Barker, T. (2005). Re-examining field sales unit performance: Insights from the resource-based view and dynamic capabilities perspective. European Journal of Marketing, 39(7/8), 885-909. https://doi.org/10.1108/03090560510601824

Morash, E. (2001). Supply Chain Strategies, Capabilities, and Performance. Transportation Journal, 41(1), 37-54.

Morash, E., Groge, C., \& Vickery, E. (1996). Strategic Logistics Capabilities for Competitive Advantage and Firm Success. Journal of Business Logistics, 17(1), 1-21.

Nguyen, D. T., \& Nguyen, T. M. T. (2009). Scientific research in business administration. Statistics Publishing.

Nunnally, J. C., \& Bernstein, I. H. (1994). Psychometric Theory (McGraw-Hill Series in Psychology) (Vol. 3). New York: McGraw-Hill.

Porter, M. E. (1985). Competitive Advantage: Creating and Sustaining Superior Performance. New York: The Free Press.

Tabachnick, B. G., \& Fidell, L. S. (2007). Using multivariate statistic. Allyn \& Bacon/Pearson Education.

Teece, D. J., Pisano, G., \& Shuen, A. (1997). Dynamic capabilities and strategic management. Strategic $\begin{array}{lll}\text { Management Journal, } & \text { 18(7), }\end{array}$ https://doi.org/10.1002/(SICI)1097-0266(199708)18:7<509::AID-SMJ882>3.0.CO;2-Z

Zott, C. (2003). Dynamic capabilities and the emergence of intraindustry differential firm performance: insights from a simulation study. Strategic Management Journal, 24(2), 97-125. https://doi.org/10.1002/smj.288

\section{Copyrights}

Copyright for this article is retained by the author(s), with first publication rights granted to the journal.

This is an open-access article distributed under the terms and conditions of the Creative Commons Attribution license (http://creativecommons.org/licenses/by/4.0/). 